\title{
TRANSAKSI OBLIGASI SYARIAH (TINJAUAN TRANSAKSI OBLIGASI MENURUT PRINSIP-PRINSIP SYARIAH)
}

\author{
Maisarah Leli \\ Program Studi Perbankan Syariah STAI YAPTIP Pasaman Barat \\ Pasaman Barat \\ e-mail: maisarah.leli@yahoo.co.id
}

\begin{abstract}
One model of economic development in the era of globalization is the rapid development of capital markets in a country. Capital market is one form of alternative fundings for business development and possesses strategic place in the framework of national development, and investment facilities for investors who have excess funds. Many investors capitalize on the capital market to conduct investment portfolios of interest, and among the options used are bonds. Indonesia which applies dual system banking system realizes that instead of transactions originating from Conventional Financial Institutions, there are also ones in Sharia Financial Institutions. Basically, the the principle differences between the conventional economic system with the syari'ab economic system is the probibition of transactions that use usury, which has been used by the Bank / Conventional Financial Institution. Syariab bonds are belived to be prospective, but their development is still hampered in technical problems and public understanding of this transaction. Less effective and efficient socialization and less familiarity of the people toward the profit and loss sharing transactions, or other sharia principles make people still think that Islamic bonds are the same as those of conventional. As a result the think that interest is identical weth profit sharing.
\end{abstract}

Kata kunci: obligasi syari'ah, dan fatwa DSN/MUI

\section{PENDAHULUAN}

P asar modal Indonesia bergerak dalam bidang saham dan obligasi, dimana saham dikelola oleh Bursa Efek Jakarta (BEJ). Sedangkan obligasi dikelola oleh Bursa Efek Surabaya (BES). Perdagangan investasi Indonesia dilihat dari tingkatannya. Pertama, dimulai dari; Risit/suku bunga; kedua, Obligasi pemerintah; ketiga, Obligasi perusahaan; keempat, reksadana; kelima, saham; keenam, opsi; ketujuh, Ficure; kedelapan, Porwar.

Perkembangan investasi di Indonesia, terkait dengan obligasi pemerintah dan obligasi perusahaan, kedua obligasi itu terdapat pada perdagangan pasar modal, yang merupakan bukti pengakuan hutang dari perusahaan (emiten). Penerbitan obligasi pemerintah sebagian besar adalah Badan Usaha Milik Negara (BUMN). Oleh karena itu emiten atau perusahaan dalam menerbitkan obligasi sangat terbatas. Keterbatasan ini membuat obligasi belum berkembang, namun seiring dengan berkembangnya perekonomian, emiten obligasi terus berkembang, tidak hanya pada BUMN tetapi juga perusahaanperusahaan swasta mulai menggunakan 
obligasi sebagai alat untuk menambah modal.

Seiring dengan berkembangnya obligasi pada perdangan pasar modal di Indonesia, penting kiranya membahas transaksi obligasi menurut prinsipprinsip syariah. Semoga pembahasan ini memberikan kontribusi terhadap perkembangan ekonomi syariah di Indonesia.

\section{PENGERTIAN OBLIGASI}

Menurut etimologi obligasi berasal dari bahasa Belanda (obligatie) yang berarti surat jaminan pemerintah. (Rahajoekoessoamah, 1995: 937)Obligasi biasanya menghasilkan bunga tetap, sedang obligasi menurut para pakar;

1. Kasmir mengemukakan bahwa obligasi adalah merupakan instrumen hutang bagi perusahaan yang hendak memperoleh modal, keuntungan dari membeli obligasi diwujudkan dalam bentuk kupon. (Kasmir, 2005: 196)

2. B. De Smalen, bahwa obligasi adalah suatu bukti hutang, yang menandai adanya suatu kewajiban perikatan. (Smalen, 1977: 15)

3. Sapto Raharjo, obligasi merupakan salah satu instrumen keuangan yang cukup menarik bagi kalangan investor di pasar modal ataupun bagi perusahaan untuk mendapatkan dana bagi kepentingan perusahaan. (Raharjo, 2004: 1)

4. Hari Sudarsono, obligasi adalah surat utang dari suatu lembaga atau perusahaan yang dijual kepada investor untuk mendapatkan dana segar. Para investor akan mendapatkan set return dalam bentuk tingkat suku bunga tertentu yang sangat bervariasi tergantung kekuatan bisnis penerbitnya. Suku bunga ini bisa dibayarkan secara tetap atau berjenjang. (Sudarsono, 2004: 222)

\section{Menurut Keputusan Menteri} Keuangan RI No. 755/KMK.011/1982. Pasal 1 (a) yang dikutip oleh Junaedi bahwa obligasi adalah jenis efek berupa surat pengakuan utang atas pinjaman uang dari masyarakat dalam bentuk tertentu, untuk jangka waktu sekurang-kurangnya tiga tahun dengan menjanjikan imbalan bunga yang jumlah setara serta saat pembayarannya telah ditentukan terlebih dahulu oleh emiten. (Junaedi, 1990: 4)

Berdasarkan pengertian obligasi yang dikemukakan oleh para pakar di atas, dapat disimpulkan bahwa obligasi adalah suatu bukti pengakuan hutang dari perusahaan yang hendak memperoleh modal, di mana terdapat bunga yang ditetapkan dan pelunasannya dilakukan dalam jangka waktu yang telah ditetapkan, atau pada saat jatuh tempo. Obligasi yang dikeluarkan perusahaan (emiten) sebagai surat berharga jangka panjang, yang bersifat hutang dengan memberikan tingkat bunga (kupon) kepada investor (pemegang obligasi) pada waktu tertentu. Adapun pengertian obligasi dalam tijauan syar'i, sebagaimana yang dikemukakan oleh Sapto Rahardjo, adalah obligasi ditawarkan dengan ketentuan yang mewajibkan emiten untuk membayar kepada pemegang obligasi syariah sejumlah pendapatan bagi hasil dan membayar kembali dana obligasi syariah pada tanggal pembayaran kembali dana obligasi 
syariah tersebut, pendapatan kembali dana obligasi syariah pada tanggal pembayaran. Pendapatan bagi hasil dibayarkan setiap periode tertentu ( 3 bulan, 6 bulan, atau setiap satu tahun). (Raharjo, 2004: 141)

Fatwa Dewan Syariah Nasional (DSN) No. 32/DSN-MUI/IX/2002, obligasi syariah adalah suatu surat berharga jangka panjang berdasarkan prinsip syariah yang dikeluarkan emiten kepada pemegang obligasi syariah yang mewajibkan emiten untuk membayar pendapatan kepada pemegang obligasi syariah berupa bagi hasil, margin, serta membayar kembali dana obligasi pada saat jatuh tempo. (Sudarsono, 2004: 223)

Besarnya pendapatan bagi hasil dihitung berdasarkan perkalian antara nasabah pemegang obligasi syariah dengan pendapatan yang dihasilkan, yang besarnya tercantum dalam laporan keuangan konsolidasi emiten triwulan yang terakhir diterbitkan sebelum tanggal pembayaran pendapatan bagi hasil kepada masing-masing pemegang obligasi syariah akan dilakukan secara proporsional sesuai dengan porsi kepemilikan obligasi syariah yang dimiliki dibandingkan dengan jumlah dana obligasi syariah yang belum dibayar kembali. (Raharjo, 2004: 141)

Di sini terlihat, bahwa obligasi syariah antara emiten dan investor mendapatkan pendapatan dari obligasi tersebut berdasarkan bagihasil pendapatan yang dibayarkan setiap periode triwulan yang besarnya tercantum dalam laporan keuangan kosolidasi emiten triwulan yang terakhir diterbitkan sebelum tanggal pembayaran pendapatan bagi hasil yang bersangkutan.
Obligasi syariah bukan merupakan hutang bunga tetap, tetapi lebih merupakan penyertaan dana yang didasarkan pada prinsip bagi hasil. Transaksinya tidak akan utang piutang melainkan penyertaan. Obligasi sejenis ini lazim dinamakan muqaradhah bond, dimana muqaradhah merupakan nama lain dari Mudharabah. Bentuk alokasi dana yang khusus dalam syariah dikenal dengan istilah Mudharabah muqayyadah. Atas pernyataannya, investor berhak mendapatkan nisbah keuntungan tertentu yang dihitung secara proporsional dan dibayarkan secara periodik. Dari persentase pembayaran yang dilakukan secara periodik, besar persentase pembayarannya berdasarkan nilai nominalnya, atau disebut dengan pembayaran kupon, yang merupakan pembagian bunga obligasi yang didasarkan atas nilai nominal yang dilakukan berdasarkan perjanjian. Penentuan tingkat kupon obligasi memasuki masa jatuh tempo pembeli obligasi akan menerima pokok pinjaman dan satu kali pembayaran kupon. Besarnya pelunasan obligasi oleh penerbit pada saat jatuh tempo akan ekuivalen dengan harganya.

\section{DASAR HUKUM OBLIGASI SYARIAH}

Pelaksanaan obligasi syariah di Indonesia dilaksanakan atas dasar hukum, yaitu : (Raharjo, 2004: 142)

1. Pendapat ulama tentang keharaman mendapatkan bunga (interest).

2. Pendapat para ulama tentang keharaman obligasi yang penghasilannya berbentuk bunga (kupon).

3. Pendapat ulama tentang obligasi syariah yang menggunakan prinsip 
Mudharabah, murabahah, musyarakah, istishna, dan salam.

4. Fatwa Dewan Syariah Nasional No. 20 DSN/TV/2001 mengenai pedoman pelaksanaan investasi reksadana syariah.

5. Fatwa dewan syariah nasional nomor: 32/DSN-MUI71X/2002 tentang obligasi syariah.

Dengan adanya fatwa MUI yang menegaskan tentang penerbitan obligasi di Indonesia, maka perusahaan (emiten) mulai menerbitkan obligasinya yang di perdagangan pada dasar modal karena boleh hukumnya obligasinya tersebut direalisasikan.

Sebagaimana Fatwa Dewan syariah nasional (DSN) No. 32/DSNMUI/DC/2002, obligasi syariah adalah suatu surat berharga jangka panjang berdasarkan prinsip syariah yang dikeluarkan emiten kepada pemegang obligasi syariah yang mewajibkan emiten untuk membayar pendapatan kepada pemegang obligasi syariah berupa bagi hasil, margin, serta membayar kembali dana obligasi pada saat jatuh tempo. (Sudarsono, 2004: 223)

Beberapa ketentuan mengenai perusahaan yang akan menerbitkan obligasi syariah yaitu : bidang usaha yang dilakukan oleh perusahaan emiten (mudharib) tidak boleh bertentangan atau berlawanan dengan konsep syariah serta harus memperhatikan fatwa DSNMU1 nomor 20/DSN-MUI/1V/2001 mengenai pedoman pelaksanaan investasi reksadana syariah.

Pendapatan (hasil) atau investasi yang dibagikan oleh perusahaan (penerbit obligasi) kepada pemegang obligasi syariah harus benar-benar halal serta tidak bertentangan dengan aturan agama Islam. (Sudarsono, 2004: 143)

\section{JENIS DAN PERINGKAT OBLIGASI}

Jenis dan peringkat obligasi yang dikenal di pasar Indonesia adalah sebagai berikut: (Sudarsono, 2004: 224)

\section{Berdasarkan Penerbitan}

1. Obligasi Pemerintah Pusat

2. Obligasi Pemerintah Daerah

3. Obligasi Badan Milik Negara

4. Obligasi Perusahaan Swasta

Ditinjau dari segi penerbitan, kasmir mengemukakan bahwa obligasi oleh pemerintah merupakan obligasi yang diterbitkan oleh pemerintah, baik pemerintah pusat, daerah atau perusahaan pemerintah. Obligasi oleh swasta adalah obligasi yang diterbitkan oleh pihak swasta. (Kasmir, 2005: 198)

Penerbitan obligasi menerima pinjaman dari pemegang obligasi dengan ketentuan-ketentuan yang sudah diatur, baik mengenai waktu jatuh tempo pelunasan hutang, bunga yang dibayarkan, besarnya pelunasan dan ketentuan lainnya. Obligasi yang tercatat di bursa efek dapat diperdagangkan dengan cara yang sama seperti transaksi saham. Harga obligasi ditentukan oleh kekuatan permintaan dan penawaran di pasar. Dalam transaksi obligasi, investor harus membayar biaya komisi (commission fee) kepada pialang, tetapi tidak dikenakan biaya transaksi (transaction fee) oleh bursa efek Jakarta.

Penerbitan obligasi disebut di depan issuer, sedangkan kontrak (perjanjian) serta syarat atau kondisi yang terdapat dalam surat obligasi dengan indenture 
(Anarogo dan Pakarti, 2003: 68). Suatu obligasi diterbitkan dengan nilai nominal yang tertentu yang akan digunakan sebagai harga pada saat penawaran. Nilai nominal ini menunjukkan jumlah utang yang harus dibayarkan, dikembalikan oleh penerbitnya pada saat jatuh tempo.

Sebagai surat hutang, penerbit obligasi melibatkan perjanjian kontrak yang mengikat antara pihak penerbit (issuer) dengan pihak pembeli pinjaman (investor). Isi perjanjian kontrak tersebut adalah:

1. Besarnya tingkat kupon serta periode pembayarannya

2. Jangka waktu jatuh tempo

3. Besarnya nominal

4. Jenis obligasi. (Sudarsono, 2004: 223)

\section{Berdasarkan Jaminan}

1. Unsecured boards/debentures atau obligasi tanpa jaminan

2. Indenture atau obligasi dengan jaminan

3. Mortgage bond atau obligasi yang dijamin dengan properti

4. Collateral trust atau obligasi yang dijamin dengan sekuritas

5. Equipment trust certificates atau obligasi yang dijamin aset tertentu.

6. Collateraaalized mortage atau obligasi yang dijamin pool of mortanges atau portofolio mortgage-backed securities.

Kasmir mengemukakan dari segi jaminan yang diberikan atau hak klaim ada dua macam, yaitu:

1. Obligasi dengan jaminan (secured bonds) merupakan obligasi yang dijamin dengan'jaminan tertentu jenis obligasi ini antara lain obligasi dengan garansi (guaranteed bonds), obligasi dengan jaminan efek (collateral trust bonds) dan obligasi dengan jaminan peralatan (equipmentbonds)

2. Obligasi tanpa jaminan (unsecured bonds) pengertian tanpa jaminan artinya obligasi, yang diberikan hanya berbentuk kepercayaan semata- mata. (Kasmir, 2005: 197)

\section{Berdasarkan Jenis Kupon}

1. Fixed rate, obligasi yang memberikan tingkat kupon tetap sejak diterbitkan hingga jatuh tempo.

2. Floating rate, obligasi yang tingkat bunganya mengikuti tingkat kupon yang berlaku di pasar

3. Mixed rate, obligasi yang memberikan tingkat kupon tetap untuk periode tertentu.

\section{Berdasarkan Peningkatannya}

1. Investment grade bonds

2. Non-investment-grade bonds

\section{Berdasarkan Kupon}

1. Coupon bonds pada obligasi berkupon

2. Zero coupon bonds, untuk obligasi nir kupon

\section{Berdasarkan Call Feature}

1. Freely callable bond, obligasi yang dapat ditarik kembali oleh penerbitnya setiap waktu sebelum masa jatuh tempo.

2. Non callable bond, setelah obligasi diterbitkan dan terjual, tidak dapat di beli/ ditarik kembali oleh penerbitnya sebelum obligasi jatuh tempo.

3. Differed callable bond adalah kombinasi antara freely callable bunds dengan non callable bond. 


\section{Berdasarkan Konversi}

1. Convertible bond, obligasi yang dapat ditukarkan saham setelah jangka waktu tertentu.

2. Non-convertible bonds, obligasi yang tidak dapat di konversi menjadi saham

\section{Jenis Obligasi Lainnya}

1. Income bonds, obligasi yang membayarkan kupon hanya jika emiten penerbitnya mendapatkan laba.

2. Guaranteed bond, obligasi yang diterbitkan oleh perusahaan tetapi tidak di dukung oleh perusahaan induk.

3. Participating bond, obligasi yang memiliki hak menerima atau laba selain penghasilan bunga secara periodik.

4. Voting bonds, obligasi yang mempunyai hak suara

5. Serial bond, obligasi yang pertunasannya berdasarkan nomor seri.

6. Inflation index bond, atau di sebut juga treasury inflation protection securities (UPS), obligasi yang nilai nominalnya (principal) selalu di sesuaikan dengan tingkat inflasi yang sedang berlaku.

Adapun jenis-jenis obligasi (Kasmir, 2005: 197) di tinjau dari segi peralihan ada dua bentuk, yaitu:

1. Obligasi atas unjuk (bearer bonds), obligasi jenis ini tidak memiliki nama dalam obligasinya dan mudah untuk dialihkan kepada pihak lain.

2. Obligasi atas nama (registered bonds), merupakan obligasi yang memiliki nama pemilik obligasi dalam obligasi dan untuk pengalihan memerlukan berbagai persyaratan dan prosedur. (Kasmir, 2005: 197)
Dari segi cara penetapan dan pembayaran bunga pokok:

1. Obligasi dengan bunga tetap, merupakan obligasi yang memberikan bunga secara tetap setiap periode tertentu

2. Obligasi dengan bunga tidak tetap, merupakan obligasi yang memberikan bunga tidak tetap dan biasanya dikaitkan dengan suku bunga yang berlaku untuk periode tertentu.

3. Obligasi tanpa bunga, merupakan obligasi yang tidak memberikan bunga kepada pemegangnya. Keuntungan dari obligasi ini di harapkan selisih nilai antara nilai pembelian dengan nilai pada saat jatuh tempo.

\section{Dari segi jatuh tempo:}

1. Obligasi jangka pendek, merupakan obligasi yang beijangka waktu tidak lebih dari 1 tahun.

2. Obligasi jangka menengah, yaitu obligasi yang memiliki jangka waktu antara 1 tahun sampai dengan 5 tahun.

3. Obligasi jangka panjang merupakan obligasi yang memiliki jangka waktu lebih dari 5 tahun.

\section{OBLIGASI SYARIAH MENURUT FATWA DSN-MUI}

Berdasarkan fatwa DSN No. 32/DSN-MUI/IX2002 menetapkan obligasi itu boleh dengan ketentuan : (Shadiq dkk, 2005: 76)

\section{Ketentuan Umum}

1. Obligasi yang tidak dibenarkan menurut syariat yaitu obligasi yang bersifat hutang dengan kewajiban membayar berdasarkan bunga 
2. Obligasi yang dibenarkan menurut syariah yaitu obligasi yang berdasarkan prinsip-prinsip syariah.

3. Obligasi syariah adalah suatu surat berharga jangka panjang berdasarkan prinsip syariah yang dikeluarkan emiten kepada pemegang obligasi syariah yang mewajibkan emiten untuk membayar pendapatan kepada pemegang obligasi syariah berupa bagi hasil, margin, serta membayar kembali dana obligasi pada saat jatuh tempo.

\section{Ketentuan Khusus}

1. Akad yang dapat digunakan dalam penerbitan obligasi syariah antara lain:
a. Mudharabah muqaradhan/qiradh
b. Musyarakah
c. Murabahah
d. Salam
e. Istina
f. Ijarah

2. Jenis usaha yang dilakukan emiten (mudharib) tidak boleh bertentangan dengan syariah dengan memperhatikan substansi fatwa DSN-MUI nomor 2O/DSN-MLMV72O01 tentang pedoman investasi untuk reksadana syariah

3. Pendapatan (hasil) investasi yang dibagikan emiten (mudharib) kepada pemegang obligasi syariah Mudharabah (shahibul maal) harus bersih dari unsur non halal

\section{PENYELESAIAN PERSELISIHAN}

Jika salah satu pihak tidak menunaikan kewajibannya atau jika terjadi perselisihan diantara pihak-pihak terkait, maka penyelesaiannya dilakukan melalui Badan Arbitrase Syariah setelah tidak tercapai kesepakatan melalui musyawarah.

Sedangkan lembaga profesi pasar modal yang terkait dengan penerbitan obligasi biasa pada umumnya, ketentuan mekanisme mengenai obligasi syariah. Adalah: (Shadiq dkk, 2005: 144)

1. Obligasi syariah harus berdasarkan konsep syariah yang hanya memberikan pendapatan kepada pemegang kepada pemegang obligasi dalam bentuk bagi hasil atau revenue Sharing serta pembayaran utang pokok pada saat jatuh tempo.

2. Obligasi syariah Mudharabah yang diterbitkan harus berdasarkan pada bentuk pembagian hasil keuntungan yang telah disepakati sebelumnya serta pendapatan yang diterima harus bersih dari unsur non halal.

3. Nisbah (rasio bagi hasil) harus ditentukan sesuai kesepakatan sebelum penerbitan obligasi.

4. Pembagian pendapatan dapat dilakukan secara periodik atau sesuai ketentuan bersama, dan pada saat jatuh tempo hal itu diperhitungkan secara keseluruhan.

5. Sistem pengawasan aspek syariah dilakukan oleh Dewan Pengawas Syariah.

6. Apabila perusahaan penerbit obligasi melakukan kelalaian atau pelanggaran syarat perjanjian, wajib dilakukan pengembalian dana investor dan harus dibuat surat pengakuan hutang.

7. Apabila emiten berbuat kesalahan atau cedera janji maka pihak investor dapat menarik dananya.

8. Hak kepemilikan obligasi syariah Mudharabah dapat di pindah tangan 
kepada pihak lain sesuai kesepakatan akad perjanjian.

Pengembangan obligasi syariah sangat mendukung pertumbuhan pasar modal Indonesia dan memberikan berbagai macam alternatif investasi bagi investor. Dalam pengembangan obligasi syariah terdapat berbagai kendala diantaranya:

1. Belum banyak masyarakat paham tentang keberadaan obligasi syariah.

2. Masyarakat syariah dikondisikan untuk menghadapi masyarakat yang kurang percaya akan keberadaan sistem yang belum dikenal. (Sudarsono, 2004: 229)

Obligasi syariah sebagai bentuk pendanaan (financing) dan sekaligus investasi (investment) memungkinkan beberapa bentuk struktur yang dapat ditawarkan untuk tetap menghindarkan pada riba. Berdasarkan hal tersebut obligasi syariah dapat memberikan:

1. Bagi hasil berdasarkan akad Mudharabah/muqaradah/qirad atau musyarakah adalah kerjasama dengan skema bagi hasil pendapatan atau keuntungan, obligasi jenis ini akan memberikan retum dengan penggunaan term indicative atau expected return karena sifatnya yang floating dan tergantung pada kinerja pendapatan yang dibagi hasil.

2. Margin berdasarkan akad murabahah atau salam atau istishna atau ijarah, dengan kadar murabahah, salam, istishna sebagai bentuk jual beli dengan skema cost basis, obligasi jenis ini akan memberikan fixed return. (Sudarsono, 2004: 227)

Di Indonesia yang digunakan dalam penerbitan obligasi syariah adalah
Mudharabah (bagi hasil pendapatan) baik yang telah diterbitkan maupun yang akan diterbitkan dalam waktu dekat, sehingga yang dikenal adalah obligasi syariah Mudharabah. Obligasi syariah Mudharabah memang telah memiliki pedoman khusus dengan disahkanya Fatwa N0.33/DSN-MUI/DC/2002. Bahwa obligasi syariah mudharabah adalah obligasi yang menggunakan akad mudharabah karena bentuk pendanaan yang paling sesuai untuk investasi dalam jumlah besar dan jangka yang relatif panjang, dapat digunakan untuk pendanaan umum (general financing), merupakan percampuran kerjasama antara modal dan jasa (kegiatan usaha) sehingga membuat stuktrunya memungkinkan untuk tidak memerlukan jaminan (collateral) atas aset yang spesifik.

Beberapa alasan yang mendasar pemilihan struktur Mudharabah, antaralain:

1. Bentuk pendanaan yang paling sesuai untuk investasi dalam jumlah besar dan $j$ angka yang relatif panjang.

2. Dapat digunakan untuk pedoman umum (general financing).

3. Mudharabah merupakan percampuran kerja sama antara modal dan jasa (kegiatan usaha) sehingga membuat strukturnya memungkinkan untuk tidak memerlukan jaminan (collateral) atas aset yang spesifik.

4. Kecenderungan regional dan global dari penggunaan struktur murabahah dan bai' bithaman ajil menjadi Mudharabah dan ijarah.

Adapun syarat-syarat untuk menerbitkan obligasi adalah sebagai berikut: (Sudarsono, 2004: 226) 
1. Aktivitas utama (core business) yang halal, tidak bertentangan dengan substansi fatwa bertentangan dengan substansi fatwa No. 20/DSNMUI/TV/2001. Fatwa tersebut menjelaskan bahwa jenis kegiatan usaha yang bertentangan dengan syariah Islam di antaranya adalah :

a. Usaha perjudian dan permainan yang tergolong jadi atau perdagangan yang di larang.

b. Usaha lembaga keuangan konvensional (ribawi) termasuk perbankan dan asuransi konvensional.

c. Usaha yang memproduksi, mendistribusikan, serta memperdagangkan makanan dan minuman haram.

d. Usaha yang memproduksi, mendistribusikan, dan menyediakan barang-barang ataupun jasa yang merusak moral dan bersifat mudharat.

2. Peringkat Investasi Grade

a. Memiliki fundamental usaha yang kuat.

b. Memiliki fundamental keuangan yang kuat.

c. Memiliki citra yang baik bagi publik.

3. Keuntungan tambahan jika termasuk dalam komponen Jakarta Islamic Index (JII)

\section{PERBEDAAN OBLIGASI SYARIAH DENGAN OBLIGASI KONVENSIONAL}

Dalam harga penawaran, jatuh tempo pokok obligasi saat jatuh tempo dalam rating antara obligasi syariah dengan obligasi konvensional tidak ada bedanya. Perbedaannya terdapat pada pendapatan dan return.

Tabel 1

Perbedaan Obligasi Syariah dengan Obligasi Konvensional

\begin{tabular}{|l|l|l|}
\hline \multicolumn{1}{|c|}{ Keterangan } & \multicolumn{1}{|c|}{ Obligasi Syariah } & Obligasi Konvensional \\
\hline I larga penawaran & $100 \%$ & $100 \%$ \\
\hline Jatukı lempo & 5 Lahuiı & - \\
\hline $\begin{array}{l}\text { Pokokobligasi saatjatuh } \\
\text { tempo }\end{array}$ & $100 \%$ & $100 \%$ \\
\hline Pendapatan & Bagihasil & Bunga \\
\hline Retum & $15,5-16 \%$ indikatif & $15,5-16 \%$ tetap \\
\hline Rating & $\mathrm{AA}+$ & $\mathrm{AA}+$ \\
\hline
\end{tabular}


Namun dalam obligasi syariah lebih kompetitif dibanding obligasi konvensional, disebabkan oleh beberapa hal berikut ini:

1. Kemungkinan perolehan dari bagi hasil pendapatan lebih tinggi dari pada obligasi konvensional

2. Obligasi syariah aman karena untuk menandai proyek prospektif

3. Bila teijadi kerugian di luar kontrol, investor tetap memperoleh aktiva

4. Terobosan paradigma, bukan lagi surat utang, tapi surat investasi. (Sudarsono, 2004: 226)

Jadi perbedaan yang mendasar dari obligasi syariah dengan adanya konvensional adalah kalau obligasi syariah berdasarkan prinsip bagi hasil di samping memakai akad-akad syariah yang berupa ijarah (sewa), Mudharabah (bagi-bagi), musyawarah, sedangkan obligasi konvensional adalah berdasarkan bunga.

\section{PENUTUP}

Dari uraian di atas dapat penulis simpulkan bahwa transaksi obligasi yang dilakukan oleh pemerintah kepada masyarakat (investor) yang ditunjuk oleh pemerintah sebagai agen penjual adalah bank Mandiri. Transaksi obligasi tersebut adalah Obligaasi Negara Ritel (ORI) dengan nomor seri ORIOOl' yang hanya satu kali luncing oleh bank Mandiri. Dalam perdagangan Obligasi Negara Ritel (ORI) dilakukan di pasar Perdana dan pasar Sekunder. Dalam pasar perdana hukumnya dibolehkan, sedangkan di pasar sekunder hukumnya dilarang karena adanya unsur capital gain.
Obligasi Negara Ritel (ORI) yang ditunjuk sebagai agen penjual oleh pemerintah adalah bank mandiri. Bank mandiri mengambil keuntungan 100\% ini juga di larang, karena bank mandiri mengambil keuntungan yang besar padahal bank hanya sebagai agen penjual.

Transaksi obligasi syariah, merupakan salah satu prospek perkembangan ekonomi Indonesia, dengan penerbitan obligasi syariah tersebut pasar investasi pada instrumen syariah akan lebih maju, dalam penerbitan obligasi syariah harus melalui proses prosedur perizinan yang berlaku dengan melibatkan pihak dewan syariah nasional (Majelis Ulama Indonesia).

Instrumen obligasi syariah di Indonesia bisa mendukung pertumbuhan pasar modal Indonesia menjadi lebih maju dan memberikan berbagai alternatif investasi bagi investor. Pasar modal syariah diharapkan mampu mendorog perumbuhan institusi-institusi (lembaga keuangan) syariah dan instrumeninstrumen syariah, salah satunya adalah obligasi syariah karena obligasi syariah dipandang prospekif sejalan dengan perkembangan lembaga keuangan syariah. Mengenai Islam dalam transaksi obligasi syariah ada yang membolehkan dan ada yang mengharamkan.

\section{DAFTAR KEPUSTAKAAN}

Al-Shadiq, Mukhtar, dkk. 2005. FatwaFatwa Ekononu Syariah Komtemporei. Jakarta : Renaisan.

Anaroga, Pandji dan Piji Pakarti. 2003. Pengantar Pasar Modal. Jakarta : Rineka Cipta. 
De Smalen, B. 1997. Pasar Modal dan Uang. Penerjemah : Hari Maroeto, Judul Asli Effectenbeurs, Effeden bedrijf en effectenver ber, Jakarta : PT Pradnya Paramita.

Direktorat Pengelolaan surat Utang Negara, Direktorat Jendral Perbendaharaan, www. Departemen Keuangan Republik Indonesia.

Junaedi. 1990. Transaksi Jual Beli Saham dan Obligasi di Pasar Modal Indonesia di Tinjau dari Segi Hukum Islam. Jakarta: Kalam Mulia.

Kasmir. 2005. Bank dan Lembaga Keuangan Lainnya. Jakarta : PT. Raja Grafindo Persada.
Koesoamah, Rahajoe. 1995. Datje, Kamus Belanda Indonesia. Jakarta : Rineka Cipta.

Rahardjo, Sapto. 2004. Panduan Investasi Obligasi. Jakarta : PT. Gramedia Pustaka Utama.

Sudarsono, Heri. 2004. Bank dan Lembaga Keuangan Syariah Deskripsi dan Ilustrasi. Yogyakarta: Ekonisia.

Tanggapan Pemerintah atas Pajak dan Biaya-biaya Obligasi Negara Ritel, www. Copy right Tempo, 2003 